\title{
Surface-groundwater interaction in unconfined sedimentary aquifer system in the Brazil's tropical wet region
}

\section{Interação entre a água superficial e subterrânea em sistema aquífero sedimentar não confinado na região tropical úmida do Brasil}

\author{
Guilherme Henrique Cavazzana $^{1}$ (D), Giancarlo Lastoria ${ }^{1}$ and Sandra Garcia Gabas ${ }^{1}$ \\ ${ }^{1}$ Universidade Federal de Mato Grosso do Sul, Campo Grande, MS, Brasil \\ E-mails: cavazzana.ea@gmail.com (GHC),g.lastoria@ufms.br (GL), sandra.gabas@ufms.br (SGG)
}

Received: August 07, 2018 - Revised: November 09, 2018 - Accepted: December 18, 2018

\begin{abstract}
Since groundwater and surface waters are important components of the hydrological system, determining their interaction is essential for the efficient management of water resources by predicting the consequences of interference, whether due to the growth of demand or due to climate change. However, integrated scientific studies on these water resources are scarce, including in the Guariroba's Environmental Protection Area, responsible for supplying 31.3\% of the Campo Grandem/MS's population, representing a local water security element. Thus, this work had as objective to evaluate the interaction between surface-groundwater in an unconfined sedimentary aquifer system, based on hydrograph separation methodologies of base flow, Flow Duration Curve (FDC) analysis, Master Recession Curve (MRC) evaluation and verification of the relationship between the surface flow, piezometric levels (PL) of the wells and the monthly precipitation. The results indicates a proportional relationship between rainfall, superficial flow and PL variations; the FDC smooth slope suggests that the baseflow is sustained by the groundwater discharge, corresponding to $89 \%$ of the total flow; the low-flow index indicates that the groundwater's storage capacity is about $80 \%$; the Base-Flow Index (BFI) ranging from 0.804 to 0.921 , indicates a stable flow regime, aquifer's high permeability conditions, though not uniform, and low runoff.
\end{abstract}

Keywords: Base flow; Barnes' graphical method; RECESS; Eckhardt's recursive digital filter; Inverse filter.

\section{RESUMO}

Sendo as águas subterrânea e superficial importantes componentes do sistema hidrológico, a determinação da sua interação é imprescindível para a gestão eficiente dos recursos hídricos por prognosticar as consequências de interferências, seja devido ao crescimento da demanda, seja devido às mudanças climáticas. Todavia, estudos científicos integrados destes meios hídricos são escassos, inclusive na Área de Proteção Ambiental do córrego Guariroba, responsável pelo abastecimento de 31,3\% dos habitantes de Campo Grande/MS, representando elemento de segurança hídrica local. Assim, este trabalho teve como objetivo avaliar a interação entre as águas superficial e subterrânea em um sistema aquífero sedimentar não confinado, a partir de metodologias de separação de hidrograma de vazões diárias, da análise das Flow Duration Curve (FDC), da avaliação da Master Recession Curve (MRC) e da verificação das variações das vazões superficiais, dos níveis piezométricos $(\mathrm{NP})$ dos poços e das precipitações mensais. Os resultados indicam uma relação proporcional entre as precipitações, as vazões superficiais e a variação dos NP, a inclinação pouco acentuada da FDC sugere que a vazão de base é sustentada pela descarga subterrânea por corresponder a 89\% da vazão total; o índice de low-flow indica que a capacidade de armazenamento subterrâneo é de cerca 80\%; o Índice de Vazão de Base (Base-Flow Index - BFI) variando de 0,804 a 0,921, indica um regime de vazão estável, condições de alta permeabilidade do aquífero, embora não uniforme, e de baixo escoamento de superficial.

Palavras-chave: Escoamento de base; Método gráfico de Barnes; RECESS; Filtro digital recursivo de Eckhardt; Filtro inverso. 


\section{INTRODUCTION}

The management of water resources in a river basin is carried out by disregarding the interactions between the groundwater and superficial water, evaluating and studying them separately, as well as proposing independent protection policies. However, the interaction between both resources is an important factor for efficient management and development of use and preservation policies.

The interaction between surface and groundwater can occur in two ways, basically, because, in most watersheds, surface and groundwater systems are connected to each other and the surface flows are controlled by changes in groundwater levels (RASSAM et al., 2013a; BRODIE et al., 2007; ALLEY; REILLY; FRANKE, 1999).

The first interaction occurs through the infiltration of surface water into groundwater, when the stream flow level is higher than the saturated zone level. The other form of interaction consists of the discharge of the groundwater to the superficial flow, denominated base flow, when the saturated zone level is higher than the streamflow level (ZHAO et al., 2018; LI et al., 2016; ABO; MERKEL, 2015a; WINTER, 1998; BEVANS, 1986).

This relationship between surface and subsurface water is associated with the concept of aquifer recharge as being an essential component of the water balance, whose discharge as a base flow is characteristic of wet climate and controlled by the hydraulic gradient between the surface water level and groundwater level (MILANO et al., 2015; ASSEFA; WOODBURY, 2013; BAKKER; BARTHOLOMEUS; FERRÉ, 2013; HEALY; SCANLON, 2012; GÓMEZ; RODRÍGUEZ; VIVES, 2010; BALOOCHESTANI, 2008; NIMMO; HEALY; STONESTROM, 2005; DE VRIES; SIMMERS, 2002).

The natural recharge of groundwater and the direction of the underground flow are influenced by the duration and intensity of precipitation, topography, soil type and geology, changes in river slope and meanders in the flow channel and by human actions (OLIVEIRA et al., 2017; MEIXNER et al., 2016; SANTOS; KOIDE, 2016; SILVEIRA et al., 2016; ABO; MERKEL, 2015b; LUCAS; WENDLAND, 2015; CASCHETTO et al., 2014; VONFREYBERG; MOECK; SCHIRMER, 2015).

Several techniques have been developed to estimate the groundwater recharge and, therefore, to study the surface-groundwater interaction. The most used physical methods consist of: direct measurement, Darcy, Flow Duration Curve (FDC) analysis, hydrograph separation and recession curve analysis. The most important chemical methods are the isotopic composition analysis and the tracer techniques. (ZHAO et al., 2018; LI et al., 2016; BAKKER; BARTHOLOMEUS; FERRÉ, 2013; SCANLON; HEALY; COOK, 2002; GAYE; EDMUNDS, 1996).

The hydrograph separation method quantifies the portion of the base flow that contributes to the total flow, resulting from the groundwater recharge. (BRODIE; HOSTETLER, 2005). The analysis of the base flow has been used in the last century, from the Boussinesq's equation (1904), whose hydrograph separation techniques were evaluated by Nathan and McMahon (1990), Tallaksen (1995), Smakhtin (2001), Brodie et al. (2007) and, recently, for Mei and Anagnostou (2015), Thomas, Vogel and Famiglietti (2015) and Lott and Stewart (2016).
However, the application of these methods requires care due to the uncertainties generated by the lack of some consideration factors that influence the water balance, such as precipitation and evaporation, as well as inaccuracies in streamflow measurement (RANTZ, 1982).

In the last two decades, some software have been developed for the application of hydrograph separation techniques, through of various types of algorithms and filters, allowing the reduction of analysis time and the complex hydrograph studies. (ARNOLD; ALLEN, 1999). Stand out the HYSEP, which offers at least 3 filters (SLOTO; CROUSE, 1996); the HydroOffice that offers 11 filters (GREGOR; MALÍK, 2012a); and the RECESS which allows to generate the Master Recession Curve (MRC) (RUTLEDGE, 1998).

Despite numerous existing methods and tools, the importance of water resources and the existence of several aquifer systems nationally, scientific studies assessing the interaction between underground and surface water resources are scarce and mostly non-integrated.

This situation is not different in the Guariroba's Environmental Protection Area (Área de Proteção Ambiental do Guariroba - APA Guariroba), which, despite representing approximately $31.3 \%$ of the total water production capacity to supply the Campo Grande's population $\left(5.000 \mathrm{~m}^{3} \cdot \mathrm{h}^{-1}\right)$ (PLANURB, 2013), the scientific technical studies carried out in the area are attributed to the physical characteristics of the watershed, justifying the accomplishment of this research, integrating the surface water and groundwater resources, assisting in the efficient and adequate management of the water resources of this watershed, adding local water security.

Thus, the objective of this study was to evaluate the potential relationship between surface water and groundwater of a watershed where the aquifer system is sedimentary and not confined and located in the Brazil's tropical region, based on surface flow variability, low-flow period, hydrograph separation and recession curve displacement analysis, considering the variations in the piezometric level (PL) and precipitation, validating the application of these methodologies, both regionally and nationally, thus assisting in the elaboration of watershed management plans and in support of decision-making for water's multiple uses.

\section{MATERIAL AND METHODS}

\section{Study area}

Due to the strategic importance for the State Capital's public supply, the Guariroba's Environmental Protection Area (APA Guariroba) was created, through Municipal Decree n. 7.183/1995. The APA Guariroba is located in the Brazilian Midwest Region, in the center of the Mato Grosso do Sul State and east of the Campo Grande/MS (Figure 1), with a total area of $362 \mathrm{~km}^{2}$ (CAMPO GRANDE, 2008).

The climatic classification is Aw type, according to the Köppen model, with rainy summer and dry winter. The average annual temperature is $23.2^{\circ} \mathrm{C}$, with abrupt variation throughout the year, minimum of $5.7^{\circ} \mathrm{C}$ in winter and maximum of $37.5^{\circ} \mathrm{C}$ in summer (CAMPO GRANDE, 2012; PLANURB, 2013). The average annual rainfall is between 1,400 to $1,500 \mathrm{~mm}$ (CPRM, 


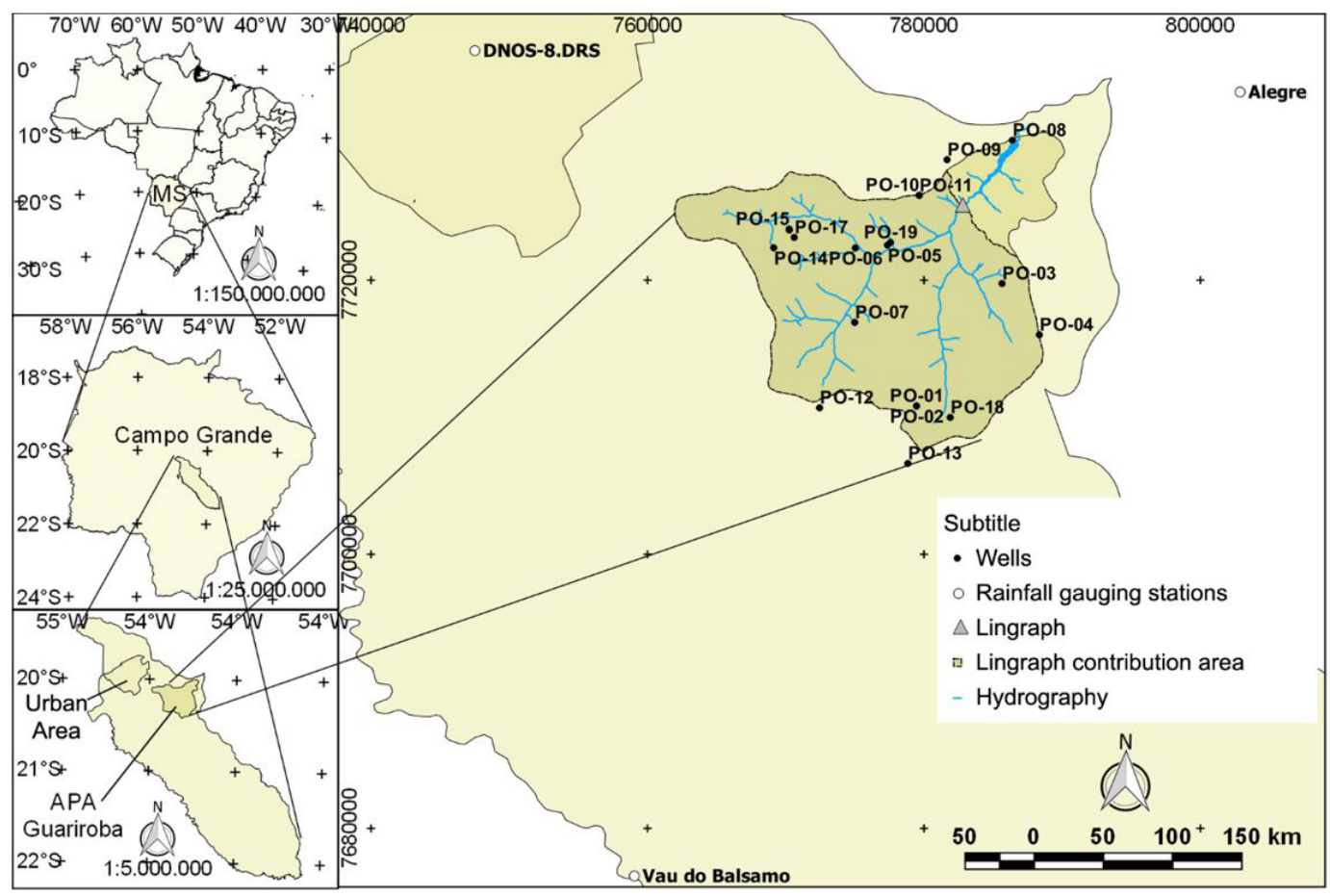

Figure 1. Study area, linigraph contribution area, linigraph, wells and rainfall gauging stations localizations.

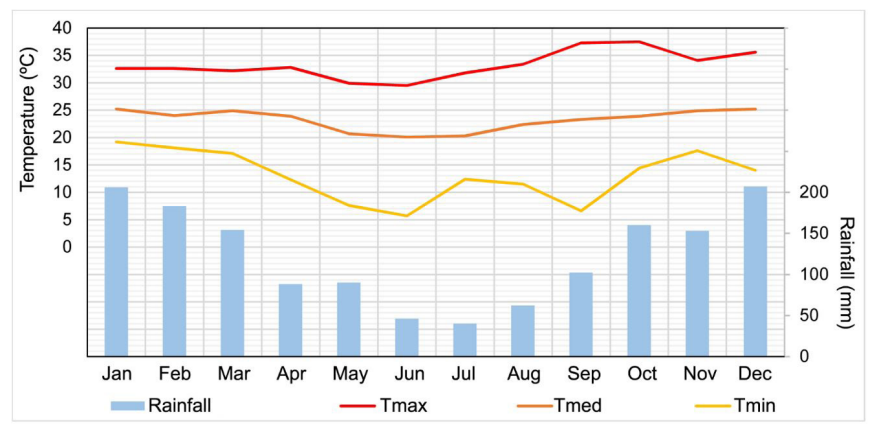

Figure 2. Monthly averages of precipitation and temperature between 1996 and 2010. Adapted from PLANURB (2013).

2011), with minimum precipitations recorded in the winter months and highs in the summer months (Figure 2).

The Guariroba stream is a tributary of the Botas stream and is included in the Rio Pardo Planning and Management Unit (Unidade de Planejamento e Gerenciamento do Rio Pardo - UPG Pardo), which, in turn, belongs to the Paraná River Basin. The main tributaries to the Guariroba stream are the streams: Rondinha, Tocos, Desbarrancado and Saltinho, which are perennial. The Guariroba reservoir, with 4.25 million $\mathrm{m}^{3}$ of dammed water, is located in the watershed's downstream (CAMPO GRANDE, 2008).

The predominate outcrop in the APA is the Caiuá Formation, while in the valley bottom the Serra Geral Formation predominates (Figure 3a). The predominant soil is the Quartzarenic Neosols of sandy texture, to a lesser extent the Red-Yellow Latosols and, associated with the fluvial plains, occur the hydromorphic and alluvial soils (CAMPO GRANDE, 2008) (Figure 3b).
The Geomorphology (Figure 3c) of the APA is predominantly of very broad hills, complemented by the fluvial plains and exposed soils, the latter two associated to the valley bottoms, where they present the lowest altimetry heights, forming the stream channels and receiving the groundwater discharge. The topography is smooth slope (4 to $8 \%$ ) and the relief ranging from 440 to $640 \mathrm{~m}$ (CAMPO GRANDE, 2008), as shown in Figure 3d.

The predominant soil use in the APA is the exotic pasture, with eucalyptus forestry advance. In the valley bottoms there are occurrences of wetlands and meadows, Cerrado biome typical formations (CAMPO GRANDE, 2008).

Regarding hydrogeological characteristics, APA is constituted by Bauru Aquifer System (Sistema Aquifero Bauru-SAB), characterized as a sedimentary and unconfined aquifer, it allows subsurface flow which is responsible for the maintenance of the drainage base level that forms the Guariroba watershed stream to its mouth in the Ribeirão Botas stream (CAMPO GRANDE, 2008).

The hydraulic parameters were determined by TAHAL and SANESUL, for the SAB outcrop area in the Mato Grosso do Sul State as: average specific capacity (q) of $0.57 \mathrm{~m}^{3} \cdot \mathrm{h}^{-1} \cdot \mathrm{m}^{-1}$;

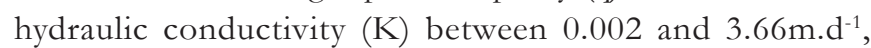
transmissivity $(\mathrm{T})$ between 0.14 and $328 \mathrm{~m}^{2} \cdot \mathrm{d}^{-1}$, effective porosity $\left(n_{\mathrm{e}}\right)$ between 10 and $15 \%$; and pumping rates (Q) of the wells between 10 and $80 \mathrm{~m}^{3} \cdot \mathrm{h}^{-1}$ (TAHAL, 1998).

The $\mathrm{SAB}$ also has a renewable annual reserve of $19.6 \times 10^{9} \mathrm{~m}^{3}$ and an annual renewable water reserve of $3.9 \times 10^{9} \mathrm{~m}^{3}$, in a recharge area of about $134.6 \times 10^{3} \mathrm{~km}^{2}$ in Mato Grosso do Sul State. The infiltration rate estimated is $10 \%$, for water balance and granting purposes; currently considered the most exploited aquifer in the State (CAMPO GRANDE, 2010). 


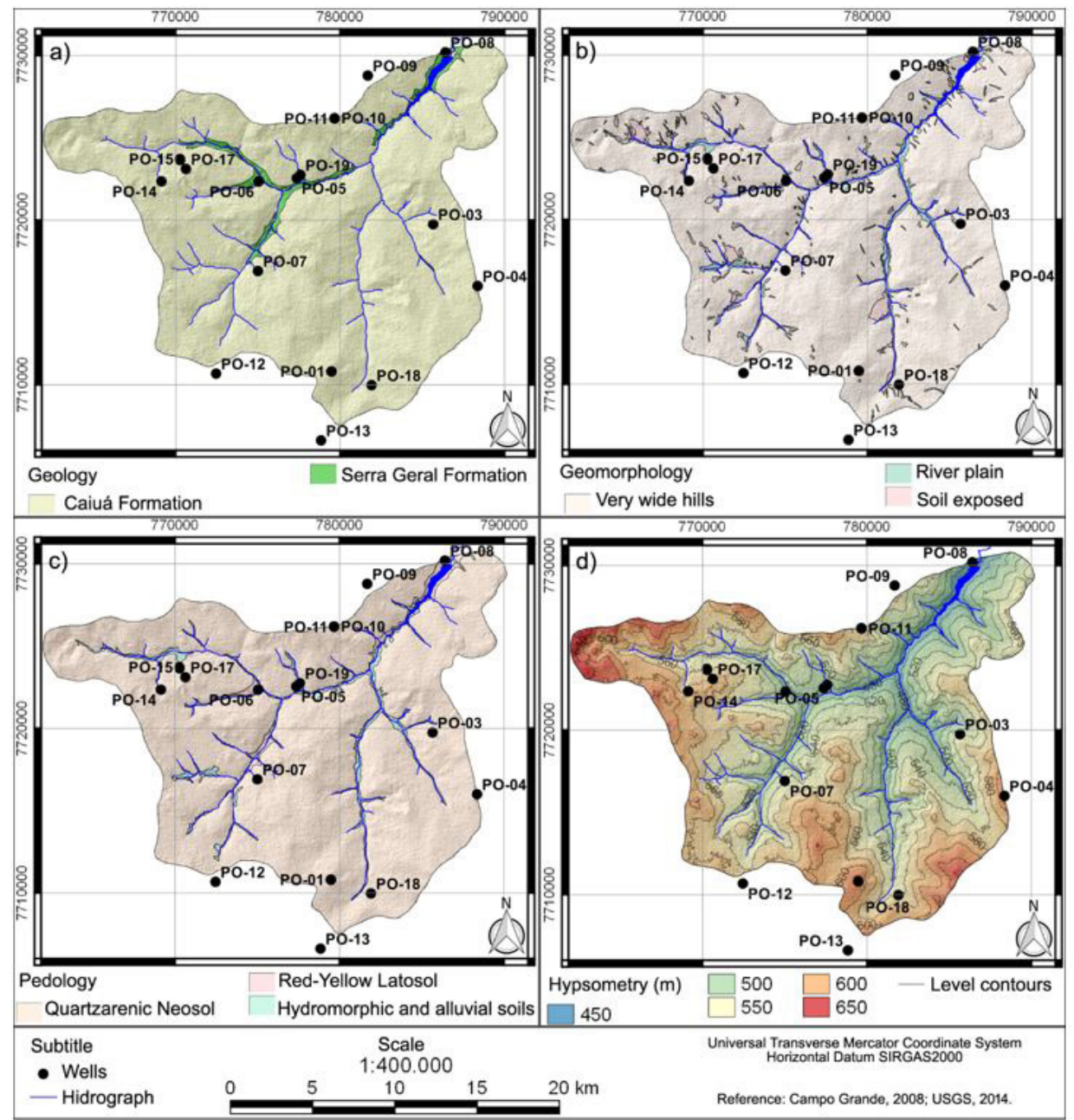

Figure 3. Maps of: (a) Geology; (b) Pedology; (c) Geomorphology; and (d) Hypsometry.

\section{Sampling information}

In this research, daily mean flow, monthly piezometric levels of wells and daily rainfall were used from March 2015 to February 2017, whose data were not faulty and covered 2 hydrological years.

The flow was measured by a lingraph with a datalogger, located upstream of the Guariroba reservoir, which was built for the Campo Grande water supply. Such a point was defined as there is no pumping interference, which is not constant throughout the day.

As the measurement point is not located in the downstream section of the APA Guariroba, automatic delimitation of the contribution area of the lingraph (Figure 1) was performed, using the digital elevation model (DEM) of the SRTM (Shuttle Radar Topography Mission) image, with spatial resolution of $30 \times 30 \mathrm{~m}$ (USGS, 2014). This technique can be better visualized in Schmitt and Moreira (2015). The delimited contribution area of the lingraph was $318.074 \mathrm{~km}^{2}$.

The measurement of the temporal variation of the piezometric levels (PL) of the production wells was realized monthly (at least 24 hours without pumping), with the use of an electronic meter of water level of the Hidromec. Although 19 wells were identified, 2 of them were not allowed to perform this research
(PO-12 and PO-13) and in 13 of them the measurements were regular enough for the elaboration of this research (Figure 1).

All the wells were measured in the same days, as well as the measurements of instantaneous flow in the Guariroba stream, using Newton's windlass, by the technique of half section and upstream of the lingraph, in order to verify its register. The methodology of flow measurement is proposed by the ANA (Agência Nacional da Agua - National Water Agency) (ANA, 2014).

The PL monthly variation of each well was plotted with the instantaneous flows, in order to analyze their relationship.

The daily rainfall data during the time period of this research were obtained from the pluviometric stations of the National Hydrological Network (Rede Hidrológica Naciona), available at ANA's SNIRH (Sistema Nacional de Informações Sobre Recursos Hidricos - National Information System on Water Resources) (CALDEIRA et al., 2015; MACÊDO et al., 2013; TUCCI, 2007).

Three rainfall gauges stations were selected that were closer to APA Guariroba, with at least 5 years of data recorded to be representative samples (TUCCI, 2007) and that had no measurement failure during the research period (Table 1).

The data used in this study were evaluated for their consistency and were compared with the values consisted available in the 
Table 1. Selected gauging stations.

\begin{tabular}{ccccc}
\hline ANA Code & Name & Latitude & Longitude & Historical Series \\
\hline 02054014 & DNOS-8.DRS & $-20^{\circ} 27^{\prime} 06^{\prime \prime}$ & $-54^{\circ} 37^{\prime} 39^{\prime \prime}$ & $1976-2017(1976-2006)$ \\
02054020 & Alegre & $-20^{\circ} 28^{\prime} 15^{\prime \prime}$ & $-54^{\circ} 05^{\prime} 48^{\prime \prime}$ & $1976-2017(1983-2006)$ \\
02154002 & Vau do Balsamo & $-20^{\circ} 59^{\prime} 38^{\prime \prime}$ & $-54^{\circ} 30^{\prime} 29^{\prime \prime}$ & $1983-2017(1983-2006)$ \\
\hline
\end{tabular}

historical series. The applied methodology was the Double Mass (TUCCI, 2007) and there was no inconsistency in the rainfall data.

To calculate daily and monthly rainfall averages, the distance-weighted-squared interpolation method was used between the rainfall gauges stations and the centroid of the study area. According to Collischonn and Dornelles (2013), such a method of spatial interpolation allows a rainfall gauge station closer to the study area to have greater weight in the calculation of average rainfall.

\section{Hydrograph analysis}

Hydrographic analysis techniques are important for the investigation of the mechanisms governing the relationship between groundwater and surface water. Its advantage is to use daily surface flows data, through the identification of the runoff and the groundwater discharge, as well as the portion that recharges the aquifers (ABO; MERKEL, 2015a). The criterion for the use of this methodology consisted in the availability of daily flow data collected from March 2015 to February 2017, thus enabling the application of the methodology.

\section{Flow Duration Curve analysis}

The Flow Duration Curve (FDC) was used to characterize the low-flow and the base flow periods, as well as to evaluate the relationship between the surface flow and groundwater discharge, by the curve shape analysis. The FDC was obtained through the elaboration of a semi-logarithmic graph between the flow (ordinate) and its frequency (abscissa), representing the probability of a certain flow occurring, also providing details of the low-flow values (RASSAM et al., 2013b).

The interpretation of the FDC occurred from the evaluation of its slope; if it were steep, runoff would prevail; if it were smooth, the base flow dominates the total flow. Also, how the FDC forms in its upper and lower parts would demonstrate the characteristics of the perennial storage of the watershed; if the lower part were a flat or steep curve, it would indicate, respectively, a high or a low storage capacity (SEARCY, 1959).

Finally, the low-flow index was evaluated from the result of the relationship between $\mathrm{Q}_{90}$ and $\mathrm{Q}_{50}$, consisting of reference flows that are $90 \%$ and $50 \%$ of the period matched or exceeded. The purpose of this relationship was to characterize the base flow variability and to indicate the contribution of the groundwater storage (NATHAN; MCMAHON, 1990). A low result of the low-flow index would represent a lower variability of the base

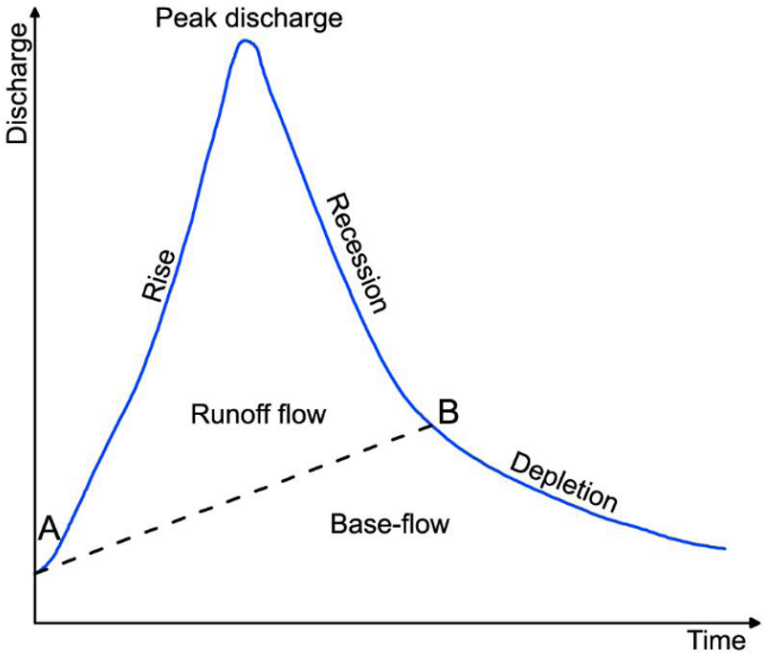

Figure 4. Schematic showing the manual hydrograph separation from Barnes' method. The segment between A, B and the time axis represents the base-flow, while the supper one is the runoff flow. Adapted of Costa and Bacellar (2010).

flow, which would sustain the flow over time as a response to groundwater storage (NELMS; HARLOW; HAYES, 1997).

\section{Base flow separation}

The importance of the quantification of the baseflow due to aquifer discharge consists in providing information on the dynamic behavior of the watershed's groundwater. According to Fetter (2001), the higher groundwater discharge capacity as the base flow is directly proportional to the hydraulic gradient between the piezometric and surface water levels.

The base flow separation can be accomplished by the application of several methods; from manuals, through the visual interpretation of hydrographs (Figure 4); even by automatic techniques.

The automatic continuous separation techniques by the Base Flow Index (BFI) was used because of its ability to divide historical series of superficial flows in to rapid flow discharge (due to direct response of runoff to a rainfall event) and in to slow flow (due to long-term discharge of the aquifer storage) (COLLISCHONN; DORNELLES, 2013; TUCCI, 2007; NATHAN; MCMAHON, 1990). 
The BFI consists of the proportion in which the base flow contributes to the total flow of the watershed and indicates the capacity of a watershed to store or release water during the dry season (TALLAKSEN, 1995).

This index is dimensionless, ranging from 0 to 1 . Results close to 1 indicate that the flow regime is relatively stable and therefore has high stream sustainability during dry periods. In impermeable watersheds with predominant surface flow regime, the index is around 0.15 ; while values close to 0.9 are found in permeable watersheds and with relatively stable flow regime (TALLAKSEN, 1995). Also watersheds that are not connected to an aquifer can have a BFI equal to 0 (WINTER, 1998).

However, this index is influenced by the hydrological properties, the geological formations and the types of soils of the watershed (GREGOR; MALÍK, 2012b).

Thus, Maillet (1905) proposed that the water storage in the aquifer and the base flow can be described mathematically as a linear relationship, based on the Boussinesq model (BOUSSINESQ, 1904), an exponential model for recession can be accepted for most of the aquifers (DEWANDEL et al., 2003), according to Equation 1, adapted by Mattiuzi et al. (2016).

$\mathrm{Q}_{(\mathrm{t}+\Delta \mathrm{t})}=\mathrm{Q}_{\mathrm{t}} \cdot \mathrm{e}^{-\Delta \mathrm{t} / \mathrm{k}}$

where: $Q_{(t+\Delta t)}$ and $Q_{t}$ are respectively the flows at the end and at the beginning of the recession period $\left(\mathrm{m}^{3} \cdot \mathrm{s}^{-1}\right), \mathrm{k}$ is the constant of the recession characteristic period (day) and $\Delta \mathrm{t}$ is the recession period (day).

The constant of the recession period $(\alpha)$ consists of the exponential portion $\left(\mathrm{e}^{-\Delta t / \mathrm{k}}\right)$ of Equation 1, while the constant of the recession characteristic period $(\mathrm{k})$ (Equation 2) is obtained from the Equation 1 mathematical development, whereas recession periods are periodic.

$$
\mathrm{k}=\frac{-\Delta \mathrm{t}}{\ln \left(\mathrm{Q}_{(\mathrm{t}+\Delta \mathrm{t})} / \mathrm{Q}_{\mathrm{t}}\right)}
$$

In order to obtain the $\alpha$ and $\mathrm{k}$ constants, three methodologies were used: Barnes' Graphical Method (SILVA, 2009), Correlation Method (MATTIUZI et al., 2016) and Master Recession Curve Method (MRC) (COSTA; BACELLAR, 2010).

The criteria for applying the Barnes' Graphical Method consisted of the possibility of using surface flow data obtained at longer time intervals than the daily ones, requiring less data and still with measurement failures (SILVA, 2009). Thus, its advantage is to enable this study to be carried out in regions with scarce primary data, where there is difficulty in obtaining data or a lack of technical and financial resources.

On the other hand, the correlation and the MRC methods were used due to the possibility of being replicated in watersheds with historical series of daily superficial flows, even if they are short and discontinuous, available in the ANA's SNIRH (ANA, 2016). These methods consider that the recession periods are cyclical and follow the same trend, although different from each other, due to the conditions precedent to rainfall events vary (soil moisture and piezometric level) (COSTA; BACELLAR, 2010; RUTLEDGE, 1998; NATHAN; MCMAHON, 1990).

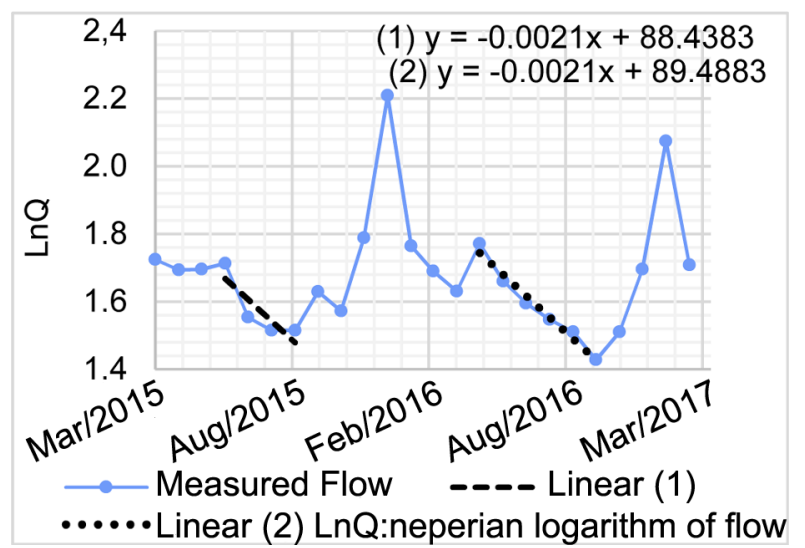

Figure 5. Hydrograph of monthly measured flows, two linear regressions of the characteristic recession periods (1 and 2) and their respective regression equations.

In turn, the MRC method was performed automatically using a software to avoid subjectivity in the manual determination of recession periods (ARNOLD; ALLEN, 1999).

For the application of the Barnes' Graphical Method, the flows were measured monthly with the Newton's windlass, which were plotted on a semi-logarithmic graph and two recession periods were identified, between June to September in 2015 and May to October in 2016.

Each recession period was linear mathematically regressed, one for each period, whose angular coefficients represent the $(-1 / \mathrm{k})$ (Figure 5$)$. Thus, the $\alpha$ constant was calculated from the average of the $\mathrm{k}$ values.

For the application of the correlation method, the periods with decreasing daily flows were identified, since there was no rainfall during the identified periods, otherwise, the decreasing flow period has been discarded (MATTIUZI et al., 2016; SMAKHTIN, 2001; TALLAKSEN, 1995; NATHAN; MCMAHON, 1990).

Another criterion used in the selection of the characteristic recession period was the coefficient $\mathrm{N}$ (Equation 3), which represents the period in days when the surface flow ceases and the streamflow being only the base flow contribution (LINSLEY; KOHLER; PAULHUS, 1958). Thus, $\mathrm{N}$ resulted in 3 days.

$\mathrm{N}=0.83 \cdot \mathrm{A}^{0.2}$

where: A is the area of contribution to the section of the lingraph, in this work, $318.074 \mathrm{~km}^{2}$.

Lastly, periods of at least 2 delay days were filtered, that represents the time interval between the end of a runoff and the beginning of another hydrograph ascension period (NATHAN; MCMAHON, 1990).

Thus, 20 recession periods were identified over 5 days ( 3 days to runoff cease and apparent recession greater than 2 days) and no precipitation.

For each period, the flows at the times $(t+\Delta t)$ and $t$ and the time interval $\Delta \mathrm{t}$ were identified, and then Equation 2 was applied to obtain the $\mathrm{k}$ constants; finally, the $\alpha$ constant was calculated from the $\mathrm{k}$ constants average. 
The third methodology used to determine the $\mathrm{k}$ and $\alpha$ constants was from the Master Recession Curve (MRC), which consists of a main curve to which the Recession Curves (RC) tend to converge (TALLAKSEN, 1995; NATHAN; MCMAHON, 1990), because in wet regions, recessions are interrupted by rainfall episodes, and thus, several short recession stages are generated, with distinct responses due to the initial condition of the watershed and the rainfall event characteristic (RUTLEDGE, 1998).

The RC automatic identification and their overlaps determination (Matching Strip Method), were performed by the RECESS tool (RUTLEDGE, 1998), with inlet flows in cubic foots per second and operated in a DOS environment.

This tool uses the coefficient $\mathrm{N}$ to disregard the runoff contribution periods as well as the base flow minimum period of 2 days. Then, these periods were plotted in a semi-logarithmic graph, performed the linear mathematical regression (Figure 6), whose angular coefficient corresponds to $(-1 / \mathrm{k})$, which made possible the calculation of $\mathrm{k}$ and $\alpha$ constants.

The $\alpha$ constant analysis had as purpose to evaluate the relationship surface-groundwater, because the greater the result value of this constant, would indicate that the base flow sustains the streamflow (ABO; MERKEL, 2015a).

According to Nathan and McMahon (1990), values ranging from 0.2 to 0.8 , are typical of runoff; between 0.8 and 0.94, intermediate flow; and between 0.93 and 0.995 , base flow.

From the $\mathrm{k}$ and $\alpha$ constants calculated by the three methods previously described, the Eckhardt's Recursive Digital Filter (ECKHARDT, 2005) and the Inverse Filter (IF) (BORGES et al., 2017) were applied to the daily flow series for the base flow separation from runoff.

The hydrograph separation techniques by the filters application are important because it allows the reduction of processing and data analysis times, complex hydrographs study and impartiality in the research (GREGOR; MALÍK, 2012b; ARNOLD; ALLEN, 1999; SLOTO; CROUSE, 1996).

The criteria for the application of Eckhardt's Recursive Digital Filter and the Inverse Filter (IF) consisted of being characterized as generalist and simple application (BORGES et al.,

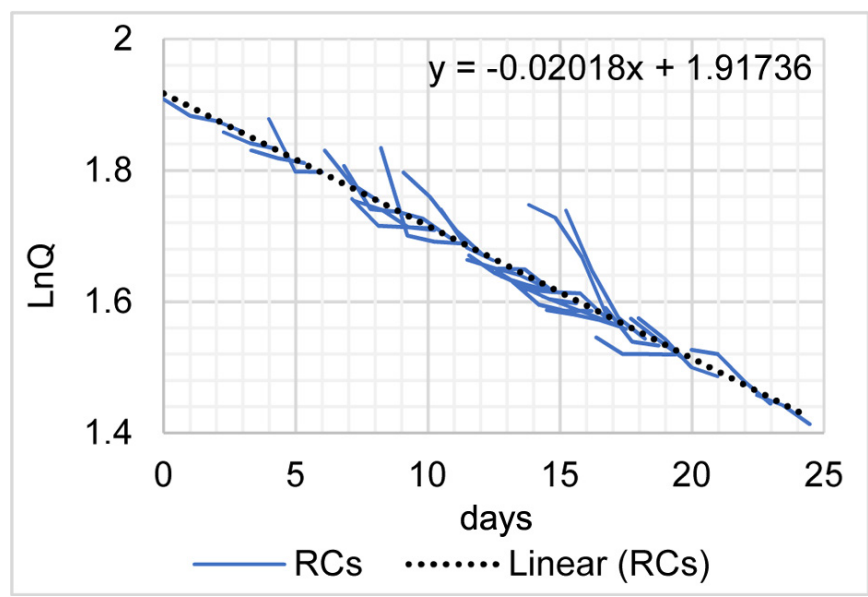

Figure 6. Master Recession Curve (MRC) obtained from the linear mathematical regression of the recession curves (RC).
2017; MATTIUZI et al., 2016; COLLISCHONN; FAN, 2013; ECKHARDT, 2005). In addition, daily flow data are available in the ANA's SNIRH (ANA, 2016), making it possible to replicate this study in other watersheds.

Eckhardt (2005) proposed that the several filters equations could be simplified from a generic equation, provided that the streamflow was equal to or greater than the base flow, at the same instant of time (Equation 4).

$\mathrm{Qb}_{\mathrm{i}}=\mathrm{A} \cdot \mathrm{Qb} \mathrm{b}_{(\mathrm{i}-1)}+\mathrm{B} \cdot \mathrm{Q}_{\mathrm{i}}$

where: $\mathrm{Qb}_{\mathrm{i}}$ is the base flow $\left(\mathrm{m}^{3} \cdot \mathrm{s}^{-1}\right) ; \mathrm{Q}_{\mathrm{i}}$ is the streamflow $\left(\mathrm{m}^{3} \cdot \mathrm{s}^{-1}\right)$; $\mathrm{A}$ and $\mathrm{B}$ are calculation parameters and $\mathrm{i}$ is the time interval (day).

The parameters A (Equation 5) and B (Equation 6) are expressed as a function of the parameter $\mathrm{BFI}_{\max }$ (Maximum Base Flow Index) and the recession period constant $(\alpha)$. The $\mathrm{BFI}_{\max }$ is the maximum value that the BFI can result.

$\mathrm{A}=\left(\frac{1-\text { BFImax }}{1-\mathrm{a} \cdot \text { BFImax }}\right) \cdot \mathrm{a}$

$\mathrm{B}=\frac{(1-\mathrm{a}) \cdot \text { BFImax }}{1-\mathrm{a} \cdot \mathrm{BFImax}}$

Collischonn and Dornelles (2013) propose that BFI $_{\max }$ parameter be calculated by Equation 7, which has adequate adjustment for the Brazil's South and Central regions, from the relation between the reference flows $\mathrm{Q}_{90}$ and $\mathrm{Q}_{50}\left(\mathrm{~m}^{3} \cdot \mathrm{s}^{-1}\right)$, for $\mathrm{BFI}_{\max }<1$.

$\operatorname{BFImax}=0.8344 \frac{\mathrm{Q}_{90}}{\mathrm{Q}_{50}}+0.2146$

Substituting Equation 5 and Equation 6 into Equation 4 gives the Eckhardt equation (Equation 8), for $\mathrm{Qb}_{\mathrm{i}} \leq \mathrm{Q}_{\mathrm{i}}$; which was applied in the average daily flows series, obtaining the average daily base flows $\left(\mathrm{Qb}_{\mathrm{i}}\right)$.

$\mathrm{Qb}_{\mathrm{i}}=\frac{(1-\mathrm{BFImax}) \cdot \mathrm{a} \cdot \mathrm{Qb}(\mathrm{i}-1)+(1-\mathrm{a}) \cdot \mathrm{BFImax} \cdot \mathrm{Q}_{\mathrm{i}}}{1-\mathrm{a} \cdot \mathrm{BFImax}}$

For the Inverse Filter Method (IF), the parameter $\mathrm{BFI}_{\max }$ was obtained from Equation 9, which consists of the division between the sum of the maximum possible base flows $\left(\mathrm{Qb}_{\mathrm{i}}^{\prime}\right)$, by the total stream flow $\operatorname{sum}\left(\mathrm{Q}_{\mathrm{i}}\right)$. In turn, $\mathrm{Qb}_{\mathrm{i}}^{\prime}$ was the result of the ratio between the base flow of a later time step $\left(\mathrm{Qb}_{(\mathrm{i}+1)}\right)$ by the recession period constant $(\alpha)$ (Equation 10), provided that $\mathrm{Qb}_{\mathrm{i}}^{\prime}<\mathrm{Q}_{\mathrm{i}}$ (BORGES et al., 2017).

$$
\begin{aligned}
& \mathrm{BFI}_{\text {max }}=\frac{\sum_{\mathrm{i}=1}^{\mathrm{N}} \mathrm{Qb}_{\mathrm{i}}^{\prime}}{\sum_{\mathrm{i}=1}^{\mathrm{N}} \mathrm{Q}_{\mathrm{i}}} \\
& \mathrm{Qb}_{\mathrm{i}}^{\prime}=\frac{\mathrm{Qb}_{(\mathrm{i}+1)}}{\alpha}
\end{aligned}
$$

\section{Conceptual methodological steps}

The methodological steps used in this research are summarized in the flowchart (Figure 7). 


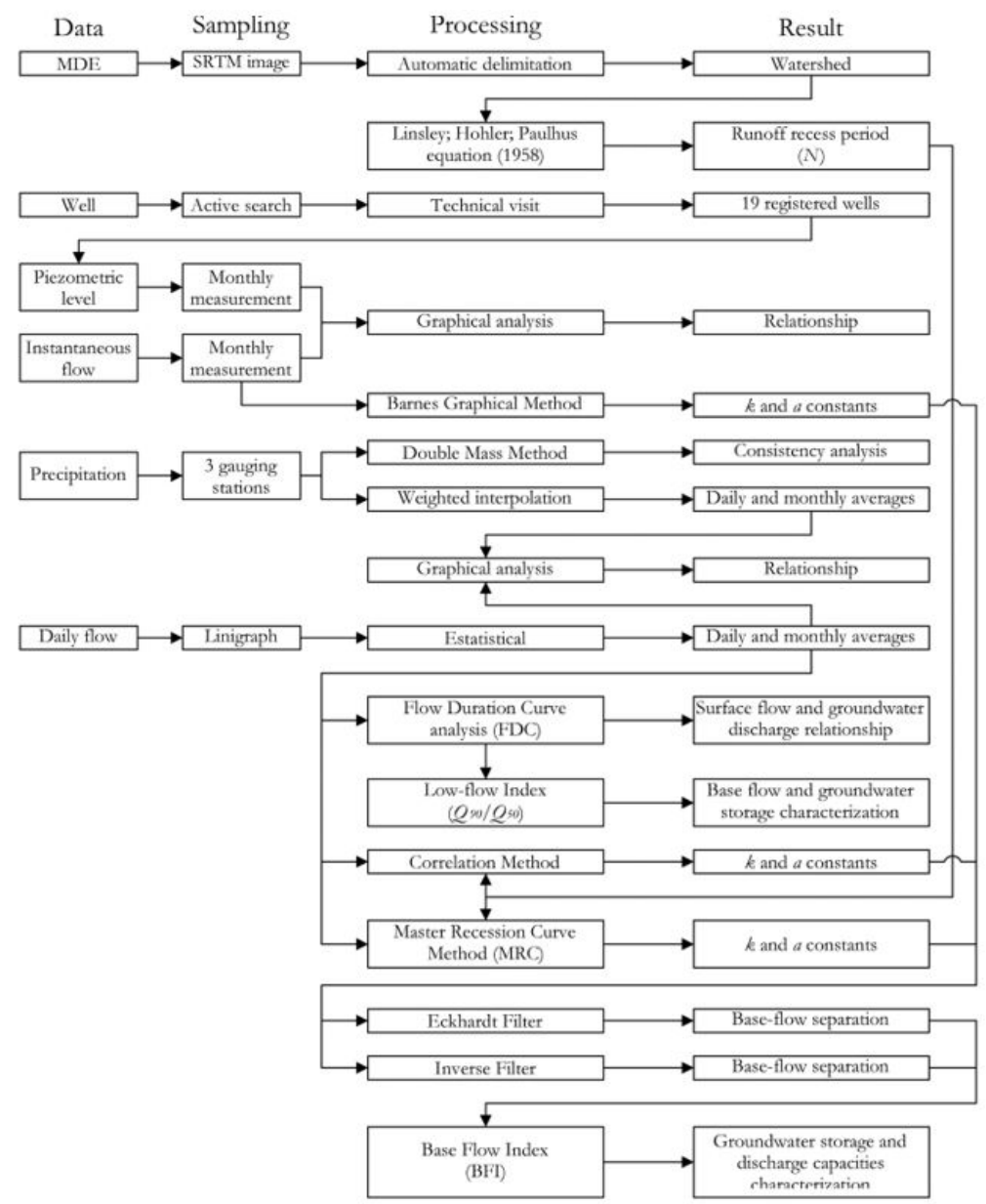

Figure 7. Conceptual flowchart summarizing the methodology steps used in this research.

\section{RESULTS AND DISCUSSIONS}

\section{Hydrological analysis}

The visual analysis of monthly PL fluctuation compared to the variation of average monthly streamflow, indicates that there is a proportional delay time relationship between the streamflow peak and PL depth between 10 and 11 months for PL with more than 60m (Figure 8, PO-01 and PO-04); between 4 and 6 months for PL between 25 and 35m (Figure 8, PO-07 and PO-10); and 1 month for PL less than $8 \mathrm{~m}$ (Figure 8, PO-08 and PO-16).

The delay time variation may be due to the influence of direct and indirect factors, among them the time period that parcel of the rainfall that infiltrates takes to cross the unsaturated zone to the saturated zone, the hydraulic properties variation of the soil and aquifer; the piezometric level and the climate (rainfall) (MATTIUZI et al., 2016; ABO; MERKEL, 2015b; WINTER, 1998).

It is important to note that, even though the aquifer is sedimentary and unconfined, there are visible texture variations in the surface coverings, which surely occur in subsurface, implying a permo-porosity heterogeneity of the layer.

The distance between the wells and the lingraph also influences the delay time variation because as the distance increases, the subsurface flows paths are longer and deeper, making the responses caused by the groundwater discharges, at the stream flow, less pronounced (ALLEY; REILLY; FRANKE, 1999).

The one-dimensional Boussinesq equation that considers the change in groundwater storage under stable conditions, as inversely proportional to the distance of the streamflow (TUCCI; HILEMAN, 1992), complementing the validation of the results obtained.

Abo and Merkel (2015a) argue that such proportional variations provide potential connection evidence between surface and groundwater. The same authors (op cit) comment that if flow rises occur during the dry season, when the piezometric level are generally at the deepest levels, it indicates that there are late groundwater discharges.

From the Figure 9 analysis, the direct relationship between the precipitation, streamflow and the piezometric levels is notorious. However, the indirect relationship may occur. Abo and Merkel (2015b) identified the occurrence of piezometric levels elevations during the dry season due to intense irrigation for the agricultural production in a Syria's arid region.

Regarding precipitation, it is necessary to show that the annual average rainfall resulted in $1,486 \mathrm{~mm}$, within the limit proposed by the CPRM (2011), which ranges 1,400 to $1,500 \mathrm{~mm}$.year ${ }^{-1}$ for the study area. 


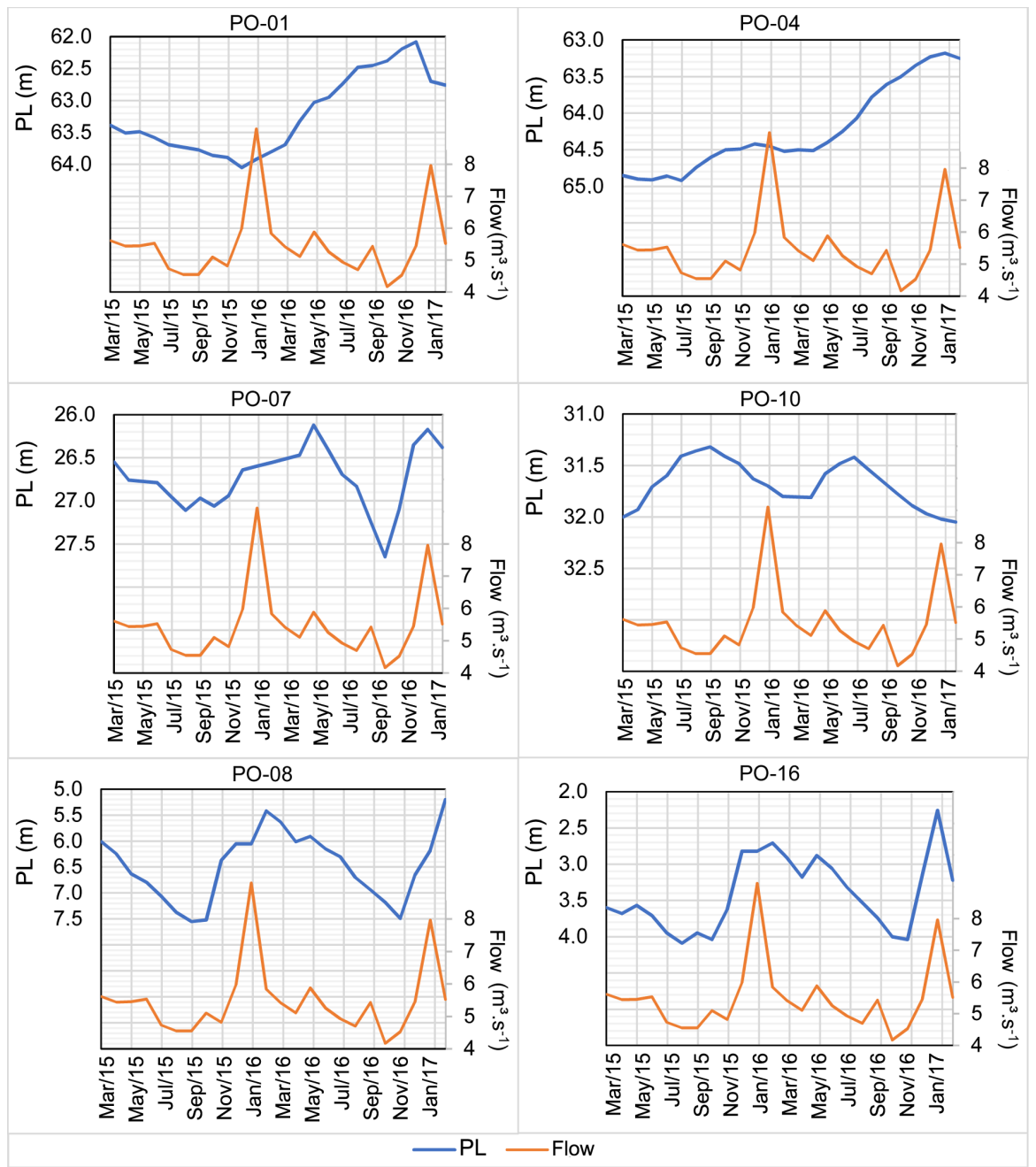

Figure 8. Monthly variations of piezometric levels (PL) and streamflow measured.

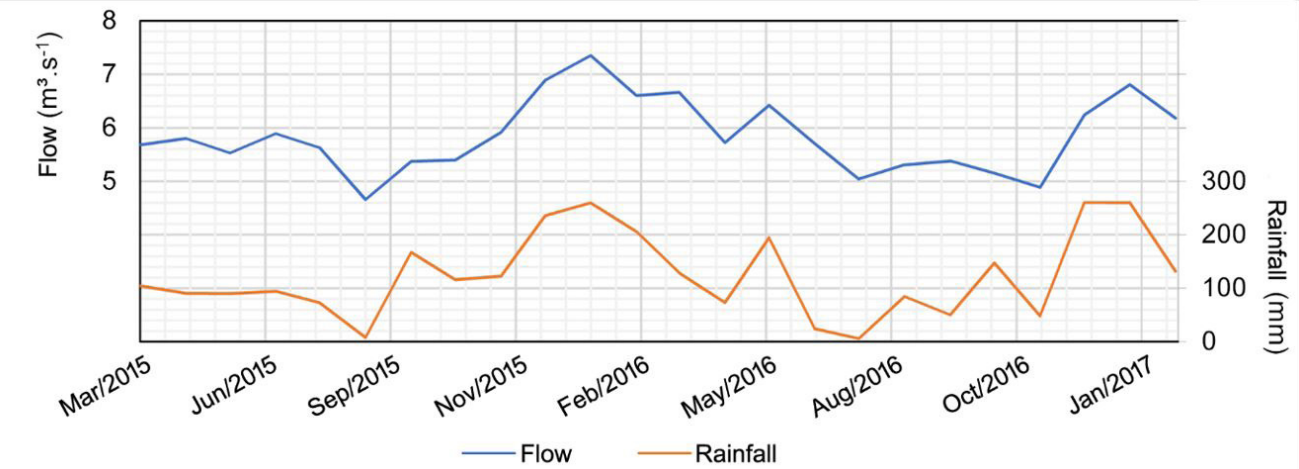

Figure 9. Monthly variations of streamflow and rainfall.

\section{FDC and MRC analysis}

From the FDC analysis, which resulted in smooth slope curves (Figure 10), it is possible to suggest that there is a significant contribution of the base flow to the total streamflow, resulting in a uniform flow sustained by the groundwater discharge.
In addition, the upper and lower portions of the FDC curves are slightly sloped, which shows a high storage capacity. It is added that from the result of the low-flow index $\left(\mathrm{Q}_{90} / \mathrm{Q}_{50}\right)$, the underground storage ratio is about $80 \%$.

In fact, the study area can be characterized as a medium to low superficial flow system and low base flow variability, because 


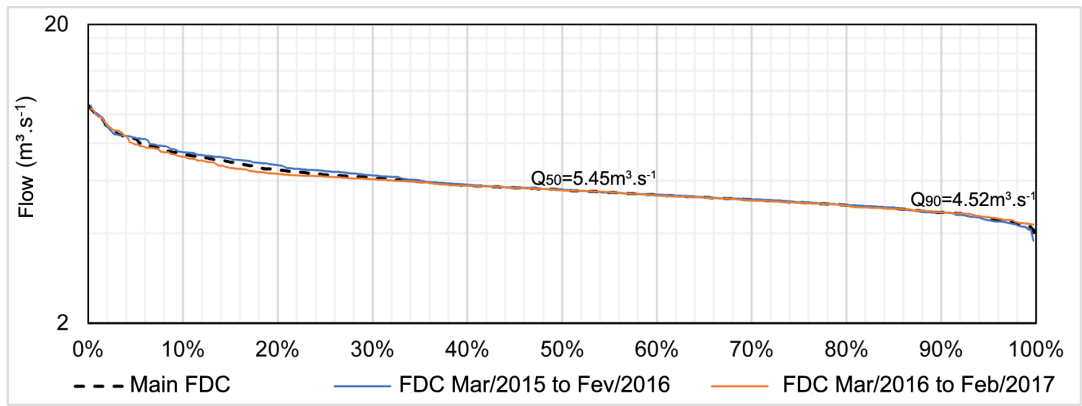

Figure 10. Flow duration curves (FDC).

the angular coefficient of the MRC (Figure 6) is close to $-0,02$, resulting in $\mathrm{k}=50$ days and $\mathrm{a}=0,98$. This a value is characteristic of temporary intermediate flows systems soon after the rainfall periods, followed by periods whose flow is maintained by the base flow (NATHAN; MCMAHON, 1990).

Abo and Merkel (2015a), whose research had been carried out in a sedimentary and unconfined watershed, but arid climate, found that the base flow was supported by the groundwater storage, according to FDC analysis. On the other hand, the proportion of groundwater storage, according to the low-flow index, ranged from 45 to $58 \%$, lower than the result obtained for the APA Guariroba. It is justified by the fact that in the Syria's arid region there is water deficit and the aquifer storage capacity is reduced due to the low rainfall availability, an inverse climatic condition to which the APA Guariroba is submitted.

\section{Base flow analysis}

The quantitative details and results obtained from $\mathrm{k}$ and a constants by the Barnes, correlation and MRC methods are shown in Table 2.

The values disparity of the $\mathrm{k}$ and a constants obtained by the Barnes' method, in relation to the correlation and MRC methods, can be explained by having been obtained from the angular coefficients of the linear math regression of monthly measured streamflow. This time period is relatively long to the watershed recession characteristic, resulting from the MRC analysis, whose rainfall responses are temporary and short-lived. In addition, the Barnes' method is more appropriate for recession periods of runoff than of base flow (HE et al., 2016; COSTA; BACELLAR, 2010).

The $\mathrm{k}$ and a constants obtained by the correlation and MRC methods translate the rapid response of the runoff to the total flow during the rainfall event and after being maintained by the groundwater discharge. The recession coefficient obtained by the MRC method represents the closest condition to the real base-flow recession of a watershed, since, theoretically, it indicates the trend that all the small recession stages converge (GREGOR; MALÍK, 2012b; HUANG; KUNG; LEE, 2011; COSTA; BACELLAR, 2010).

The base flows variation obtained by the hydrograph separation technique, from the Eckhardt's (Figure 11a) and Inverse (Figure 11b) filters application, for each of the $\alpha$ constants (Table 2), demonstrates the base flows disparity resulting from the $\alpha$ constant application obtained by the Barnes' method in both filters.

Quantitatively, the base flow is dominant in the study area, contributing annually to the total flow between 81.93 and $93.14 \%$, and on average $89.45 \%$ (Table 3). The results demonstrates that there was an increase in the base flow contribution in the second year of the research, reflecting the higher rainfall and, consequently, greater groundwater storage and discharge

According to Miller et al. (2016) and Costa and Bacellar (2010), watersheds that presented greater water availability resulted in greater base flow proportions due to their direct and proportional relationship to the storage capacity, being the main factors that influence this availability are the geological, geomorphological, pedological and climatic characteristics.

Mattiuzi et al. (2016) verified that the more permeable the soil and aquifer characteristics, the higher the aquifer recharge rates, in watersheds on subtropical climatic influence in southern Brazil, justifying the greater capacity of the APA Guariroba to possess high groundwater availability due to its infiltration capacity resulting from its permeable lithologic and geological frameworks.

Despite the resultant difference of the $\alpha$ constant, obtained by the Barnes' method, the results of the proportion of the base flow contribution to the total flow converged to the same percentage.

According to the results of the monthly average BFI, which ranged from 0.804 to 0.921 , indicates permeable conditions of the watershed, stable flow regime, high base flow contribution and low runoff (Table 4).

Abo and Merkel (2015a) obtained that the base flow was dominant at the total flow, ranging between 86.3 and $88.2 \%$, and that the BFI resulted between 0.8 and 0.9 , indicating that the perennial flow of the watershed was maintained by the groundwater discharge, high permeability of the aquifer and low runoff, in a Syria's arid region. Mattiuzi et al. (2016) verified that permeable geological frameworks had good capacity of regularization of the ascension and recession flow in response to a rainfall event. Conditions are similar to the results obtained for the APA Guariroba, justified by the aquifer geological characteristic to be sedimentary and unconfined which favors the infiltration and the subsurface flow.

In turn, Zhao et al. (2018) verified in a China's arid region from the hydrochemical techniques application, that the groundwater discharge as the base flow is not dominant over the runoff, because the BFI resulted between 0.2 and $8.2 \%$. It is justified by the geological characteristics of the watershed to be composed of fine clay sediments, which hinders the rainfall 
Table 2. Average values of the parameters used to obtain the a constants by different methods.

\begin{tabular}{cccccc}
\hline \multirow{2}{*}{ Parameters } & \multicolumn{3}{c}{ Methods } & Averages & $\begin{array}{c}\text { Standard } \\
\text { deviations }\end{array}$ \\
\cline { 2 - 4 } & Barnes & Correlation & MRC & & 0.12 \\
$\boldsymbol{Q}_{\boldsymbol{t}}\left(\mathrm{m}^{3} \cdot \mathbf{s}^{-1}\right)$ & 5.47 & 5.24 & 5.52 & 5.41 & 0.25 \\
$\boldsymbol{Q}_{(\boldsymbol{t}+\Delta \boldsymbol{t})}\left(\mathrm{m}^{\mathbf{3}} \cdot \mathbf{s}^{-1}\right)$ & 4.54 & 4.96 & 5.13 & 4.88 & 40.30 \\
$(\boldsymbol{t}+\Delta \boldsymbol{t})$ (days) & 88.96 & 3.25 & 3.68 & 31.96 & 0.0079 \\
$(-1 / \boldsymbol{k})$ & -0.0021 & -0.0169 & -0.0202 & -0.0131 & 198.92 \\
$\boldsymbol{k}$ (days) & 476.19 & 59.05 & 49.55 & 194.93 & 0.0078 \\
$\boldsymbol{a}$ & 0.9979 & 0.9832 & 0.9800 & 0.9870 & \\
\hline
\end{tabular}

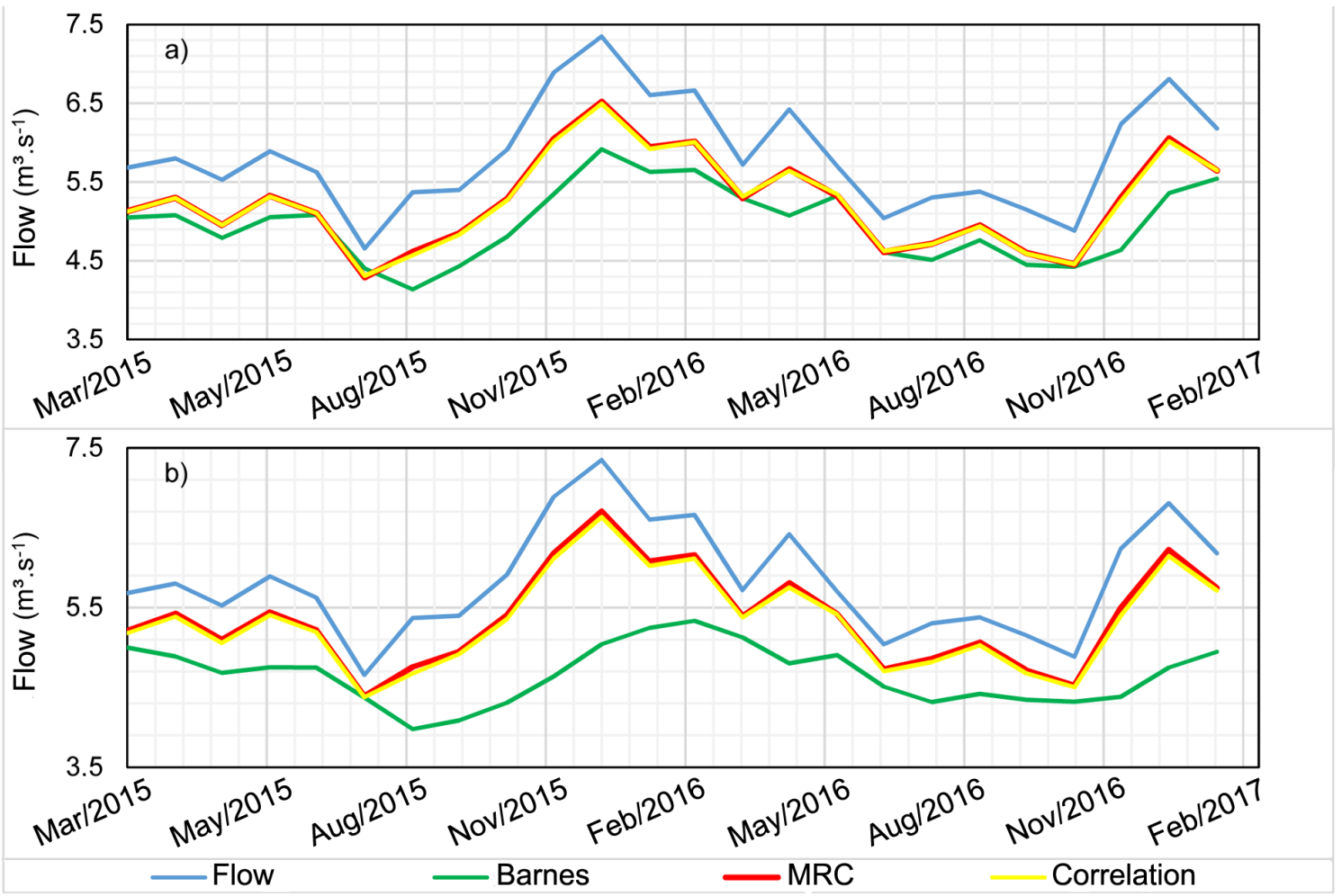

Figure 11. Total and base flows separated using different filters ((a) Eckhardt and (b) Inverse Filter) and a constants.

Table 3. Average values of the total flow $(\overline{\mathrm{Q}})$, base flow $(\overline{\mathrm{Qb}})$ and base-flow contribution $(\overline{\mathrm{BFI}})$ to the total flow, obtain by different filters and a constants.

\begin{tabular}{|c|c|c|c|c|c|c|c|}
\hline \multirow{2}{*}{ Period } & \multirow{2}{*}{ Parameter } & \multicolumn{3}{|c|}{ Eckhardt } & \multicolumn{3}{|c|}{ Inverse Filter } \\
\hline & & Barnes & Correlation & MRC & Barnes & Correlation & MRC \\
\hline \multirow[t]{3}{*}{ mar/2015-feb/2016 } & $\bar{Q}\left(\mathrm{~m}^{3} \cdot \mathrm{s}^{-1}\right)$ & \multicolumn{6}{|c|}{5.89} \\
\hline & $\overline{Q b}\left(\mathrm{~m}^{3} \cdot \mathrm{s}^{-1}\right)$ & 4.98 & 5.27 & 5.28 & 4.64 & 5.36 & 5.40 \\
\hline & $\overline{B F I}(\%)$ & 86.52 & 90.83 & 90.95 & 81.14 & 92.27 & 92.93 \\
\hline \multirow[t]{3}{*}{ mar/2016-feb/2017 } & $\bar{Q}\left(\mathrm{~m}^{3} \cdot \mathrm{s}^{-1}\right)$ & \multicolumn{6}{|c|}{5.79} \\
\hline & $\overline{Q \boldsymbol{Q b}}\left(\mathrm{m}^{3} \cdot \mathrm{s}^{-1}\right)$ & 4.97 & 5.21 & 5.22 & 4.678 & 5.30 & 5.35 \\
\hline & $\overline{B F I}(\%)$ & 87.53 & 91.23 & 91.27 & 82.71 & 92.73 & 93.35 \\
\hline \multirow[t]{3}{*}{ Average } & $Q\left(\mathrm{~m}^{3} \cdot \mathrm{s}^{-1}\right)$ & \multicolumn{6}{|c|}{5.84} \\
\hline & $Q b\left(\mathrm{~m}^{3} \cdot \mathrm{s}^{-1}\right)$ & 4.97 & 5.24 & 5.25 & 4.66 & 5.33 & 5.38 \\
\hline & $B F C(\%)$ & 87.03 & 91.03 & 91.11 & 81.93 & 92.50 & 93.14 \\
\hline \multirow[t]{3}{*}{ Standard deviation } & $Q\left(\mathrm{~m}^{3} \cdot \mathrm{s}^{-1}\right)$ & \multicolumn{6}{|c|}{1.13} \\
\hline & $Q b\left(\mathrm{~m}^{3} \cdot \mathrm{s}^{-1}\right)$ & 0.49 & 0.66 & 0.68 & 0.37 & 0.69 & 0.72 \\
\hline & $B F C(\%)$ & 11.70 & 9.14 & 8.79 & 12.24 & 8.57 & 7.99 \\
\hline
\end{tabular}


Table 4. Monthly average and standard deviation of the BFI using different filters and a constants.

\begin{tabular}{|c|c|c|c|c|c|c|}
\hline \multirow{2}{*}{ BFI } & \multicolumn{3}{|c|}{ Eckhardt } & \multicolumn{3}{|c|}{ Inverse Filter } \\
\hline & Barnes & Correlation & MRC & Barnes & Correlation & MRC \\
\hline Minimum & 0.743 & 0.843 & 0.850 & 0.673 & 0.865 & 0.881 \\
\hline Maximo & 0.946 & 0.938 & 0.934 & 0.939 & 0.950 & 0.951 \\
\hline Average & 0.855 & 0.898 & 0.900 & 0.804 & 0.914 & 0.921 \\
\hline Standard deviation & 0.056 & 0.023 & 0.020 & 0.074 & 0.020 & 0.017 \\
\hline
\end{tabular}

infiltration and subsurface flow, aggravated by the climatic condition of water deficit.

Statistically, the IF method associated to the use of the $\alpha$ constant obtained by the MRC method, resulted in more consistent values than the other methods and constants, due to the lower value of the standard deviation (0.017).

The techniques used in this research provided estimates of aquifer conditions from easily acquired and low cost data, even that short or discontinuous historical series, thus contributing to the hydrogeological characterization of regions with lacking information or data about the groundwater conditions, as in the case of the APA Guariroba.

The practical application of this research and its results will be to help the adequate planning and management of the water resources in the Mato Grosso do Sul State, since, besides being unpublished at the State level, make it possible to determine the interaction between surface and groundwater for each Water Resources Planning and Management Units (Unidade de Planejamento e Gerenciamento de Recursos Hidricos - UPG), as well as how the change in one resource can affect the other; not dissociating them and reaching the conjunctive and integrated planning and management (FOSTER; AIT-KADI, 2012).

\section{CONCLUSIONS}

From this research, it is concluded that:

- The relationship between surface water and groundwater resulted in high interaction, both by the base flow and by the groundwater storage;

- The piezometric levels variation of in shallower wells occurs more rapidly in response to dry or wet climatic seasons; in addition, the closer the wells are to the streamflow, the shorter the contribution time to the total flow;

- The base flow is sustained by groundwater storage due to the low-flow index result of $80 \%$ and the FDC smooth slope;

- The high permeability condition, although not homogeneous, low runoff and high contribution of the base flow to the total flow are due the high result of the BFI monthly average (between 0.804 and 0.921 );

- The correlation and MRC methods to obtain the $\alpha$ constant and the Eckhardt's and Inverse Filters was adequate for hydrograph separation and for surface water and groundwater relationship analyze; in contrast the Barnes' method is inappropriate for short recession periods (a few days) of base flow;
- The extension of this study to the Water Resources Planning and Management Units (UPG) of the Mato Grosso do Sul State will result in the knowledge of the superficial and groundwater interactions regionally, assisting in the conjunctive and integrated planning and management of the water resources;

- Finally, it is recommended to verify the results obtained in this research from stable isotope hydrochemical methodologies, as well as the accomplishment of geophysical survey for the aquifer lithological heterogeneity confirmation.

\section{ACKNOWLEDGEMENTS}

To CNPQ for the financial support, Process No. 477667/2013-9, Notice for Universal Call - MCTI/CNPq No. 14/2013, as well as the team that makes up this Research Project. To the Guariroba Watershed Conservation and Protection Association (Associação de Recuperação Conservação e Proteção da Bacia do Guariroba - ARCP Guariroba) for the authorization of data collection. To the Catholic University Dom Bosco (Universidade Católica Dom Bosco-UCDB) for the supply of Newton's Windlass. To the researchers Dr. Fernando M. Fan and Eng. Camila D. P. Mattiuzi for the technical assistance.

\section{REFERENCES}

ABO, R. K.; MERKEL, B. J. Investigation of the potential surfacegroundwater relationship using automated base-flow separation techniques and recession curve analysis in $\mathrm{Al}$ Zerba region of Aleppo, Syria. Arabian Journal of Geosciences, v. 8, n. 12, p. 1054310563, 2015a. http://dx.doi.org/10.1007/s12517-015-1965-6.

ABO, R. K.; MERKEL, B. J. Comparative estimation of the potential groundwater recharge in Al Zerba catchment of Aleppo basin, Syria. Arabian Journal of Geosciences, v. 8, n. 3, p. 1339-1360, 2015b. http://dx.doi.org/10.1007/s12517-013-1222-9.

ALLEY, W. M.; REILLY, T. E.; FRANKE, O. L. Sustainability of ground-water resources. Geological Survey Circular, v. 1186, p. 79, 1999.

ANA - AGÊNCIA NACIONAL DE ÁGUAS. Medição de descarga líquida em grandes rios: manual técnico. 2. ed. Brasília: ANA, 2014.

ANA - AGÊNCIA NACIONAL DE ÁGUAS. Sistema Nacional de Informações sobre Recursos Hídricos. Brasília: ANA, 2016. Available from: <www.snirh.gov.br>. Access on: 20 dec. 2016. 
ARNOLD, J. G.; ALLEN, P. M. Automated methods for estimating baseflow and ground water recharge from streamflow records. Journal of the American Water Resources Association, v. 35, n. 2, p. 411 424, 1999. http://dx.doi.org/10.1111/j.1752-1688.1999.tb03599.x.

ASSEFA, K. A.; WOODBURY, A. D. Transient, spatially varied groundwater recharge modeling. Water Resources Research, v. 49, n. 8, p. 4593-4606, 2013. http://dx.doi.org/10.1002/wrcr.20332.

BAKKER, M.; BARTHOLOMEUS, R. P.; FERRÉ, T. P. A. Groundwater recharge: processes and quantification. Hydrology and Earth System Sciences, v. 17, n. 7, p. 2653-2655, 2013. http:// dx.doi.org/10.5194/hess-17-2653-2013.

BALOOCHESTANI, F. Estimation of bydraulic properties of the shallow aquifer system for selected basins in the Blue Ridge and the Piedmont physiographic provinces of the southeastern U.S. using streamflow recession and baseflow data. Atlanta: Departmente of Geosciences, Georgia State University, 2008.

BEVANS, H. E. Estimating stream-aquifer interactions in coal areas of eastern Kansas by using streamflow records. In: SUBITZKY, S. (Ed.). Selected papers in the hydrologic sciences. Reston: US Geological Survey, 1986. p. 51-64.

BORGES, V. M.; FAN, F. M.; REGINATO, P. A. R.; ATHAYDE, G. B. Groundwater recharge estimating in the Serra Geral aquifer system outcrop area - Paraná State, Brazil. Águas Subterrâneas, v. 31, n. 4, p. 338, 2017.

BOUSSINESQ, J. Recherches théoriques sur l'écoulement des nappes d'eau infiltrées dans le sol et sur le débit des sources. Journal de Mathématiques Pures et Appliquées, v. 10, p. 5-78, 1904.

BRODIE, R. S.; HOSTETLER, S. A review of techniques for analysing baseflow from stream hydrographs. In: NZHS-IAHNZSSS 2005 Conference, 2005, Auckland, New Zealand. Proceedings... New Zealand: New Zealand Hydrological Society, 2005.

BRODIE, R.; SUNDARAM, B.; TOTTENHAM, R.; HOSTETLER, S.; RANSLEY, T. An overview of tools for assessing groundwater-surface water connectivity. Canberra: Bureau of Rural Sciences, 2007. p. 133.

CALDEIRA, T. L.; BESKOW, S.; MELLO, C. R.; FARIA, L. C.; SOUZA, M. R.; GUEDES, H. A. S. Modelagem probabilística de eventos de precipitação extrema no estado do Rio Grande do Sul Probabilistic modelling of extreme rainfall events in the Rio Grande do Sul state. Revista Brasileira de Engenharia Agricola e Ambiental, v. 19, n. 3, p. 197-203, 2015. http://dx.doi.org/10.1590/1807-1929/ agriambi.v19n3p197-203.

CAMPO GRANDE. Plano de manejo da Área de Proteção Ambiental dos mananciais do córrego Guariroba (APA) do Guariroba. Campo Grande, 2008.

CAMPO GRANDE. Secretaria de Estado de Meio Ambiente do Planejamento da Ciência e Tecnologia - SEMAC. Instituto de
Meio Ambiente de Mato Grosso do Sul. Plano Estadual de Recursos Hidricos de Mato Grosso do Sul. Campo Grande: Editora UEMS, 2010.

CAMPO GRANDE. Prefeitura. Plano municipal de saneamento básico:gestão integrada de resíduos sólidos. Campo Grande, 2012.

CASCHETTO, M.; BARBIERI, M.; GALASSI, D. M. P.; MASTRORILLO, L.; RUSI, S.; STOCH, F.; DI CIOCCIO, A.; PETITTA, M. Human alteration of groundwater-surface water interactions (Sagittario River, Central Italy): implication for flow regime, contaminant fate and invertebrate response. Environmental Earth Sciences, v. 71, n. 4, p. 1791-1807, 2014. http://dx.doi. org/10.1007/s12665-013-2584-8.

COLLISCHONN, W.; DORNELLES, F. Hidrologia para engenharia e ciências ambientais. 2. ed. Porto Alegre: ABRH, 2013.

COLLISCHONN, W.; FAN, F. M. Defining parameters for Eckhardt's digital baseflow filter. Hydrological Processes, v. 27, n. 18, p. 2614-2622, 2013. http://dx.doi.org/10.1002/hyp.9391.

COSTA, F. M.; BACELLAR, L. A. P. Caracterização hidrogeológica de aquíferos a partir do fluxo de base. Revista Brasileira de Recursos Hidricos, v. 15, n. 3, p. 173-183, 2010. http://dx.doi.org/10.21168/ rbrh.v15n3.p173-183.

CPRM - SERVIÇO GEOLÓGICO DO BRASIL. Levantamento da geodiversidade: projeto atlas pluviométrico do Brasil, isoetas anuais médias período 1977 a 2006. Brasília, 2011. p. 2.

DE VRIES, J. J.; SIMMERS, I. Groundwater recharge: an overview of process and challenges. Hydrogeology Journal, v. 10, n. 1, p. 5-17, 2002. http://dx.doi.org/10.1007/s10040-001-0171-7.

DEWANDEL, B.; LACHASSAGNE, P.; BAKALOWICZ, M.; WENG, P.; AL-MALKI, A. Evaluation of aquifer thickness by analysing recession hydrographs: application to the Oman ophiolite hard-rock aquifer. Journal of Hydrology, v. 274, n. 1-4, p. 248-269, 2003. http://dx.doi.org/10.1016/S0022-1694(02)00418-3.

ECKHARDT, K. How to construct recursive digital filters for baseflow separation. Hydrological Processes, v. 19, n. 2, p. 507-515, 2005. http://dx.doi.org/10.1002/hyp.5675.

FETTER, C. W. Applied hydrogeology. 4th ed. Upper Saddle River: Prentice-Hall, 2001.

FOSTER, S.; AIT-KADI, M. Integrated Water Resources Management (IWRM): how does groundwater fit in? Hydrogeology Journal, v. 20, n. 3, p. 415-418, 2012. http://dx.doi.org/10.1007/ s10040-012-0831-9.

GAYE, C. B.; EDMUNDS, W. M. Groundwater recharge estimation using chloride, stable isotopes and tritium profiles in the sands of northwestern Senegal. Environmental Geology, v. 27, n. 3, p. 246-251, 1996. http://dx.doi.org/10.1007/BF00770438. 
GÓMEZ, A. A.; RODRÍGUEZ, L. B.; VIVES, L. S. The Guarani aquifer system: estimation of recharge along the Uruguay-Brazil border. Hydrogeology Journal, v. 18, n. 7, p. 1667-1684, 2010. http:// dx.doi.org/10.1007/s10040-010-0630-0.

GREGOR, M.; MALÍK, P. User manual for RC. Slovakia: Hydro Office, 2012a. p. 1-36.

GREGOR, M.; MALÍK, P. Construction of master recession curve using genetic algorithms. Journal of Hydrology and Hydromechanics, v. 60 , n. 1, p. 3-15, 2012b. http://dx.doi.org/10.2478/v10098012-0001-8.

HE, S.; LI, S.; XIE, R.; LU, J. Baseflow separation based on a meteorology-corrected nonlinear reservoir algorithm in a typical rainy agricultural watershed. Journal of Hydrology, v. 535, p. 418-428, 2016. http://dx.doi.org/10.1016/j.jhydrol.2016.02.010.

HEALY, R. W.; SCANLON, B. R. Estimating groundwater recharge. Cambridge: Cambridge University Press, 2012.

HUANG, Y. P.; KUNG, W. J.; LEE, C. H. Estimating aquifer transmissivity in a basin based on stream hydrograph records using an analytical approach. Environmental Earth Sciences, v. 63, n. 3, p. 461-468, 2011. http://dx.doi.org/10.1007/s12665-010-0712-2.

LI, J.; QI, Y.; ZHONG, Y.; YANG, L.; XU, Y.; LIN, P.; WANG, S.; HE, J. Karst aquifer characterization using storm event analysis for Black Dragon springshed, Beijing, China. Catena, v. 145, p. 30-38, 2016. http://dx.doi.org/10.1016/j.catena.2016.05.019.

LINSLEY, R. K.; KOHLER, M. A.; PAULHUS, J. L. Hydrology for engineers. 1st ed. New York: McGraw-Hill, 1958.

LOTT, D. A.; STEWART, M. T. Base flow separation: a comparison of analytical and mass balance methods. Journal of Hydrology, v. 535, p. 525-533, 2016. http://dx.doi.org/10.1016/j.jhydrol.2016.01.063.

LUCAS, M.; WENDLAND, E. Recharge estimates for various land uses in the Guarani aquifer system outcrop area. Hydrological Sciences Journal, v. 61, n. 7, p. 1253-1262, 2015.

MACÊDO, M. N. C.; DIAS, H. C. T.; COELHO, F. M. G.; ARAÚJO, E. A.; SOUZA, M. L. H.; SILVA, E. Rainfall and flow of the Riozinho do Rôla Basin on Western Amazon. Ambiente \& Agua: An Interdisciplinary Journal of Applied Sciences, v. 8, n. 1, p. 445-458, 2013.

MAILLET, E. Essais d'bydraulique souterraine et fluviale. Paris: A. Hermann, 1905.

MATTIUZI, C. D. P.; KIRCHHEIM, R.; COLLISCHONN, W.; FANET, F. M. Estimativa de recarga subterrânea a partir da separação de escoamento de base na bacia hidrográfica do Rio Ibicuí (América do Sul). Águas Subterrâneas, v. 29, n. 3, p. 285, 2016.

MEI, Y.; ANAGNOSTOU, E. N. A hydrograph separation method based on information from rainfall and runoff records. Journal of
Hydrology, v. 523, p. 636-649, 2015. http://dx.doi.org/10.1016/j. jhydrol.2015.01.083.

MEIXNER, T.; MANNING, A. H.; STONESTROM, D. A.; ALLEN, D. M.; AJAMI, H.; BLASCH, K. W.; BROOKFIELD, A. E.; CASTRO, C. L.; CLARK, J. F.; GOCHIS, D. J.; FLINT, A. L.; NEFF, K. L.; NIRAULA, R.; RODELL, M.; SCANLON, B. R.; SINGHA, K.; WALVOORD, M. A. Implications of projected climate change for groundwater recharge in the western United States. Journal of Hydrology, v. 534, p. 124-138, 2016. http://dx.doi. org/10.1016/j.jhydrol.2015.12.027.

MILANO, M.; REYNARD, E.; KÖPLIN, N.; WEINGARTNER, R. Climatic and anthropogenic changes in Western Switzerland: impacts on water stress. The Science of the Total Environment, v. 536, p. 12-24, 2015. http://dx.doi.org/10.1016/j.scitotenv.2015.07.049. PMid:26188528.

MILLER, M. P.; BUTO, S. G.; SUSONG, D. D.; RUMSEY, C. A. The importance of base flow in sustaining surface water flow in the Upper Colorado River Basin. Water Resources Research, v. 52, n. 5, p. 3547-3562, 2016. http://dx.doi.org/10.1002/2015WR017963.

NATHAN, R. J.; MCMAHON, T. A. Evaluation of automated techniques for base flow and recession analyses. Water Resources Research, v. 26, n. 7, p. 1465-1473, 1990. http://dx.doi.org/10.1029/ WR026i007p01465.

NELMS, D. L.; HARLOW, G. E.; HAYES, D. C. Base-flow characteristics of streams in the Valley and Ridge, the Blue Ridge, and the Piedmont physiographic provinces of Virginia. U.S. Geological Survey Water-Supply Paper, v. 2457, p. 54, 1997.

NIMMO, J. R.; HEALY, R. W.; STONESTROM, D. A. Aquifer recharge. In: ANDERSON, M. G. (Ed.). Encyclopedia of Hydrological Sciences. New York: John Wiley \& Sons, 2005. p. 2229-2246.

OLIVEIRA, P. T. S.; LEITE, M. B.; MATTOOS, T.; NEARING, M. A.; SCOTT, R. L.; OLIVEIRA XAVIER, R.; SILVA MATOS, D. M.; WENDLAND, E. Groundwater recharge decrease with increased vegetation density in the Brazilian cerrado. Ecobydrology, v. 10, n. 1, p. 1-8, 2017. http://dx.doi.org/10.1002/eco.1759.

PLANURB - INSTITUTO DE PLANEJAMENTO URBANO DE CAMPO GRANDE. Plano municipal de saneamento básico de Campo Grande/MS. Campo Grande, 2013.

RANTZ, S. E. Measurement and computation of streamflow. U.S. Geological Survey Water-Supply Paper, v. 2175, n. 631, p. 313, 1982.

RASSAM, D. W.; PEETERS, L.; PICKET'T, T.; JOLLY, I.; HOLZ, L. Accounting for surface-groundwater interactions and their uncertainty in river and groundwater models: a case study in the Namoi River, Australia. Environmental Modelling \& Software, v. 50, p. 108-119, 2013a. http://dx.doi.org/10.1016/j.envsoft.2013.09.004.

RASSAM, D. W.; PEETERS, L.; PICKETTT, T.; JOLLY, I.; HOLZ, L. Accounting for surface-groundwater interactions and their 
uncertainty in river and groundwater models: a case study in the Namoi River, Australia. Environmental Modelling \& Software, v. 50, p. 1, 2013b. http://dx.doi.org/10.1016/j.envsoft.2013.09.004.

RUTLEDGE, A. T. Computer programs for describing the recession of ground-water discharge and for estimating mean ground-water recharge and discharge from streamflow records-update. Reston: U.S. Geological Survey, 1998. p. 52. Water-Resources Investigations Report 98-4148.

SANTOS, R.; KOIDE, S. Avaliação da recarga de águas subterrâneas em ambiente de Cerrado com base em modelagem numérica do fluxo em meio poroso saturado. Revista Brasileira de Recursos Hídricos, v. 21, n. 2, p. 451-465, 2016. http://dx.doi.org/10.21168/rbrh. v21n2.p451-465.

SCANLON, B. R.; HEALY, R. W.; COOK, P. G. Choosing appropriate technique for quantifying groundwater recharge. Hydrogeology Journal, v. 10, n. 1, p. 18-39, 2002. http://dx.doi. org/10.1007/s10040-001-0176-2.

SCHMIT'T, A.; MOREIRA, C. R. Manejo e gestão de bacia hidrográfica utilizando o software gratuito Quantun-GIS. Revista Cultivando o Saber, p. 125-137, 2015.

SEARCY, J. K. Flow-duration curves. U.S. Geological Survey WaterSupply Paper, v. 1542-A, p. 33, 1959.

SILVA, R. F. G. Estimativa de parâmetros bidrodinâmicos de aquiferos em áreas de embasamento através de métodos indiretos. 2009. $112 \mathrm{f}$. Dissertação (Mestrado em Evolução Crustal e Recursos Naturais) - Universidade Federal de Ouro Preto, Ouro Preto, 2009.

SILVEIRA, L.; GAMAZO, P.; ALONSO, J.; MARTÍNEZ, L. Effects of afforestation on groundwater recharge and water budgets in the western region of Uruguay. Hydrological Processes, v. 30, n. 20, p. 3596-3608, 2016. http://dx.doi.org/10.1002/hyp.10952.

SLOTO, R. A.; CROUSE, M. Y. Hysep: a computer program for streamflow hydrograph separation and analysis. Reston: U.S. Geological Survey, 1996. p. 54. Water-Resources Investigations Report 96-4040.

SMAKHTIN, V. U. Low flow hydrology: a review. Journal of Hydrology, v. 240, n. 3-4, p. 147-186, 2001. http://dx.doi.org/10.1016/ S0022-1694(00)00340-1.

TAHAL - CONSULTING ENGINEERS LTD. SANESUL EMPRESA DE SANEAMENTO DE MATO GROSSO DO
SUL. Relatório final: estudos hidrogeológicos de Mato Grosso do Sul. Campo Grande, 1998.

TALLAKSEN, L. M. A review of baseflow recession analysis. Journal of Hydrology, v. 165, n. 1-4, p. 349-370, 1995. http://dx.doi. org/10.1016/0022-1694(94)02540-R.

THOMAS, B. F.; VOGEL, R. M.; FAMIGLIETTTI, J. S. Objective hydrograph baseflow recession analysis. Journal of Hydrology, v. 525, p. 102-112, 2015. http://dx.doi.org/10.1016/j.jhydrol.2015.03.028.

TUCCI, C. E. M. Hidrologia: ciência e aplicação. 4. ed. Porto Alegre: UFRGS, 2007.

TUCCI, P.; HILEMAN, G. E. Potential effects of dredging the South Fork Obion River on ground-water levels near Sidonia, Weakley County, Tennessee. Reston: U.S. Geological Survey, 1992. p. 16. Scientific Investigations Report 90-4041.

USGS - UNITED STATES GEOLOGICAL SURVEY. Imagem SRTM1S21W055V3. Reston, 2014.

VONFREYBERG, J.; MOECK, C.; SCHIRMER, M. Estimation of groundwater recharge and drought severity with varying model complexity. Journal of Hydrology, v. 527, p. 844-857, 2015. http:// dx.doi.org/10.1016/j.jhydrol.2015.05.025.

WINTER, T. C. Ground water and surface water: a single resource. Denver: U.S. Geological Survey, 1998. p. 87. (Geological Survey Circular, 1139).

ZHAO, D.; WANG, G.; LIAO, F.; YANG, N.; JIANG, W.; GUO, L.; LIU, C.; SHI, Z. Groundwater-surface water interactions derived by hydrochemical and isotopic (222Rn, deuterium, oxygen-18) tracers in the Nomhon area, Qaidam Basin, NW China. Journal of Hydrology, v. 565, p. 650-661, 2018. http://dx.doi.org/10.1016/j. jhydrol.2018.08.066.

\section{Authors contributions}

Guilherme Henrique Cavazzana: Responsible for the development of the research project.

Giancarlo Lastoria: Supervisor teacher of the research project.

Sandra Garcia Gabas: Joint supervisor teacher of the research project. 